\title{
Colonialism and Narratives of Human Origins in Asia and Africa
}

Sheela Athreya ${ }^{1}$ and Rebecca Rogers Ackermann ${ }^{2}$

${ }^{1}$ Department of Anthropology, Texas A\&M University, College Station, TX USA

${ }^{2}$ Human Evolution Research Institute, Department of Archaeology, University of Cape Town, Cape Town, South Africa

\section{ACCEPTED MANUSCRIPT}

In: Interrogating Human Origins: Decolonisation and the Deep Past. M Porr and J Matthews, Eds. Archaeological Orientation Series. Routledge: Abingdon. (Series editors: Christopher Witmore and Gavin Lucas). 


\begin{abstract}
In their seminal works on postcolonialism, Edward Saïd (in Orientalism) and V.Y. Mudimbe (in The Idea of Africa) proposed that Asia and Africa, respectively, were constructs created around the notion of their otherness. Both regions were viewed as infantile, primitive, and homogenous entities that fell outside the domain of civilized (i.e. Western) humanity. These constructs shaped scientific perceptions of both continents over the course of several centuries and have continued to be operative over the last 100 years following the discovery of fossil human ancestors, particularly within the narratives of recent human origins. Here we reflect on these narratives, both in the early days of the discoveries and more recently, in the context of the othered identities of the continents more broadly. We argue that a colonialist socio-political framework has shaped the science of human origins since its inception, and that this has negatively affected the quality of this endeavour. Existing phylogenies cannot be divorced from those ideologies-even today. Indeed, while the details of human origins (e.g. when, where, who) have changed radically over time, the narrative that emerged always left one group in control, and marginalised non-Western lands and their peoples, leaving the ordering of superior and inferior more or less unchanged through the history of the discipline. More informed models of human evolution cannot be constructed until the community of voices constructing them is reworked to be more inclusive of many worldviews.
\end{abstract}


"The cultural marginalization by Orientalism is up against the physical centrality of Africa." (Ali A. Mazrui, 2005. The Re-invention of Africa: Edward Saïd, V. Y. Mudimbe, and Beyond, p 79)

\section{Introduction: The "othering" of Asia and Africa}

The concept of "otherness," or alterity, has been a part of academic discourse since George Herbert Mead's 1934 Mind, Self and Society. Within this discourse, Edward Saïd's Orientalism (1978) and V.Y. Mudimbe's The Idea of Africa (1994) were watershed works that implicated Europeans in constructing Asian and African identities and histories as "other," i.e., culturally marginalized and devalued in contrast to the European West. Both Saïd and Mudimbe tracked the historical developments over the course of many centuries that produced an Asia and an Africa that shared primitive, infant-like identities. In some respects, Asia's and Africa's constructed identities differed. For Asia, what Saïd calls the Oriental was described as fallen, irrational, stubborn, and alien, and Asia more broadly was remote, stagnant and unchangeable. European culture gained strength by setting itself up in contradistinction to the constructed identity of the Orient; framing the latter as inferior was necessary as a foil to create Western superiority. European knowledge about the Orient gave them the power and the privilege to speak for Asians (Saïd 1978). For Africa, its people were considered ape-like, savage, barbaric, and sexualised, and its resources a commodity to be acquired; it was a continent in need of civilizing. Mudimbe refers to the "blank slate" perception of Africa as terra nullis. He shows how this characterization allowed European colonists to rationalize paternalistic colonial policies that replaced African cultures and identities with their own. Whereas in Asia the civilization was no longer (i.e. fallen), in Africa the civilization never was (Mudimbe 1994).

In addition to this, Saïd and Mudimbe showed that Western scholars were engaged in the deliberate homogenization of both continents, reducing their vast diversity and complex histories into singular, geographically and temporally bounded entities to be described, owned, and to varying degrees controlled.

"The point is that in each of these cases the Oriental is "contained" and "represented" by dominating frameworks... But at the outset one can say that so far as the West was concerned during the $18^{\text {th }}$ and $20^{\text {th }}$ centuries, an assumption had been made that the Orient and everything in it was, if not patently inferior to, then in need of corrective study by the West." (Saïd 1978: 40-41).

"Only from the $18^{\text {th }}$ century on is there, thanks to the Enlightenment, a "science" of difference: anthropology. It "invents" an idea of Africa. Colonialism will elaborate upon the idea." (Mudimbe 1994: 30) 
This clear and longstanding practice of otherization has been at the heart not just of Western sociopolitical policies and agendas, but also the ostensibly objective practice of Western science (Palladino \& Worboys, 1993).

Our thesis in this chapter is that human origins research is not immune to these influences, and therefore cannot be divorced from the stereotypes upon which this sociopolitical landscape of othering, as described by Saïd, Mudimbe, and others, was built. Because the unfolding of human origins research not only happened over the time period when these Asian and African identities were being created but was also focused directly on the material resources-both fossil and human-of these two continents, these colonialist ideologies are baked into human origins research and narratives. Indeed, we argue that these colonial ideologies, and the language and practices that perpetuate them, persist over time despite often radical shifts in the details of the location, timing, and ordering of evolutionary events. Our intent is not only to unpack this relationship between colonialism and human origins research, but to offer a means for reflection and self-correction going forward.

\section{The emergence and construction of human origins narratives in colonial Asia and Africa}

The debate over an African versus Asian origin of humans has deep roots in the history of evolutionary theory, and provides insight into how prevailing social norms influenced scientific opinion about the "humanness" of people from those regions. Long before Darwin, early natural historians were organizing their understanding of human variation through the lens of "otherness." Polygenism and degeneracy theory took as their starting points the belief that non-Europeans were biologically inferior to whites, and sought merely to explain why. This view initially emerged from a Christian theological agenda, but was reworked as a biological argument after the Darwinian revolution to explain the subhuman origins of Africans, Asians, and Native Americans (Popkin, 1974; Sussman 2014).

Following the publication of On the Origin of Species, Darwin himself explored human evolution in more depth in The Descent of Man, (1871) where he noted the similarities between African apes and humans. He posited, based on this shared anatomy, that our ancestors most likely came from Africa-a view that had been expressed earlier by Huxley (1863). Darwin's assertion within the context of his newly developed evolutionary theory was significant because it implied that humanity's deepest roots were African, and were shared by all living populations. While his contemporaries agreed with his theory of evolution, not all of them agreed with the idea of Africa's fundamental humanity and thus 
weighed in based what they thought of the "civility" of the various ape species, filtered through what they thought of the humanity of Asians versus Africans. Victorian perceptions of Asians as more civilized than Africans no doubt played into their preferences as well.

A main player in the early debate about the locality of human origins was Ernst Haeckel, whose own estimations of comparative anatomy situated the roots of humankind in Asia, not Africaspecifically in a now-sunken land in the Indian Ocean which he referred to as "so-called Paradise, cradle of the human race." In his widely translated History of Creation (Haeckel, 1876) he embraced Darwin's theory of evolution and the idea of an "ape-man," and was the first to refer to it as Pithecanthropus, a name that would later be assigned to the earliest finds of what is now referred to as Homo erectus. His focus on Asia was shared by Wallace (1889), who in his essay Darwinism Applied to Man, noted the widespread distribution of phenotypically similar populations deriving from North Asia, notably Native Americans and Pacific Islanders. This belief led him to argue that Asia gave rise to our ancestors who then dispersed into Africa, Western Europe, and the Americas. The idea of an Asian root for the human tree was fleshed out in the most detail by biologist St. George Jackson Mivart who emphasized the similarities between humans and gibbons and downplayed those seen between humans and African apes (Mivart, 1873). He, therefore, gave great weight to traits such as the human-like liver of gibbons (vs. the "brutal" liver of gorillas), the apparent chin and "aquiline nose" of the siamang and Hoolock gibbon, their propensity to walk bipedally when on the ground and, most notably, their monogamy. The seemingly civilized gibbons were thus a more appealing ancestor to (Western European male) humans, and this played a significant factor in shifting the focus from Africa to Asia in the search for the "missing link."

Ultimately, this focus on Asia's superiority to Africa in general, and the "civilized" nature of the gibbon in particular, influenced one of the most instrumental figures in early paleoanthropology, Dutch naturalist Eugène Dubois. As Shipman and others have shown, based on his belief in our gibbon ancestry (and the fact that Indonesia was Dutch colony), Dubois honed in on Southeast Asia in his search for human ancestors (Trinkaus and Shipman 1993; Shipman, 2001; Shipman and Storm 2002). Dubois' discovery of the Trinil skullcap on Java, Indonesia in 1891 and his billing of it as the "missing link" received a great deal of attention and led to further explorations in the region. Throughout the early 1900s, paleontological research in East Asia by Westerners was extremely common and formed the basis for Osborn's Central Asia Theory of human origins (Osborn, 1926), an idea that had first been proposed by W. D. Matthew (1914). Prominent Western paleontologists such as Anderssen, Zdansky, 
Osborn, Tielhard de Chardin, and Black situated their research within this framework, which posited that the Central Asian plateau was the most likely place to find the most "advanced" forms of early humans (see Dennell 2018). They thus devoted their fieldwork labor to studying ancient geological deposits throughout South, Southeast, and East Asia to search for evidence of early human evolution.

This early debate on the African vs. Asian roots of human ancestry reflects two phenomena that shaped paleoanthropology from its inception. First, following the transition from theological to naturalistic explanations of human biology and origins, natural historians nonetheless continued promoting an agenda of European superiority using the veil of science to justify their views on the inferiority of non-Europeans. And second, as Saïd and Mudimbe point out, they actively constructed an interpretive framework for the study of the peoples in these regions, founded on a colonialist hierarchy that placed Europe above Asia, and situated Africa at the bottom.

Interpretations of early fossil finds in the 1910s and 1920s illustrate this hierarchy well. The Piltdown fossil (later revealed as a hoax) from Sussex, England was reported in 1912, and promoted as evidence of the European epicenter of human origins (Keith 1925; Trinkaus and Shipman 1992). When actual hominin fossils were discovered at the Broken Hill mine in Zambia in 1921 that again raised the possibility that Africa could have played a role in human evolution, researchers positioned them as younger than Neanderthals, thereby retaining the centrality of Europe and the marginalization of Africa in how they storied the origin of humans (Keith, 1925; Woodward, 1922; see also Henke, 2007). None of the British scholars reporting on the Broken Hill cranium following its discovery conceived of the true antiquity that humans had in Africa (Gregory, 1927; MacCurdy, 1922; Osborn, 1927; Woodward, 1922), and asserted their support of Piltdown as the earliest evidence of human antiquity.

The earliest truly ancient hominin in the fossil record came in 1925 with announcement of the Taung child (Australopithecus africanus) from South Africa. The Australian-born Raymond Dart had gone to South Africa in 1922 to take up the post of chair of anatomy at the University of Witwatersrand. He, along with Robert Broom, a Scottish doctor who had settled in South Africa, was the first to recognize that this fossil provided the first solid evidence of the connection between African apes and humans, i.e., the "missing link" or "ape-man" in Africa. But despite being a prominent news story, Dart's A. africanus specimen was seen by many as representing nothing more than "the extreme southward thrust of the chimpanzee stock after it had separated from man" (Gregory 1927, p 399), and moreover was initially downplayed in part because it was an anomalous find from an otherwise barren continent (Reader, 1988), sidelined by the Piltdown specimen that was more consistent with the narrative about 
European vs. African roots of humanity. In addition, soon after Dart announced his find from Taung, the first "Peking Man" skulls were excavated from Zhoukoudian in northeastern China. The wealth of discoveries there, along with additional fossil crania emerging from Java beginning in 1931, effectively rendered both Dart's southern ape of Africa and the Broken Hill skull from Zambia mere side-notes in global models of human evolution for decades. Although some anthropologists were willing to contemplate the possibility that Dart and Broom were right in situating ancient human origins in Africa (Gregory \& Hellman, 1938; Le Gros Clark, 1947; Leakey, 1936), it took until the 1950s, with the revelation that Piltdown was a hoax along with an active east African program in paleoanthropology by the Leakeys, for most scholars to shift their focus more fully to Africa.

Assumptions about the centrality of Europe were also brought to bear on questions about the recent direct ancestry of $H$. sapiens (i.e. modern human origins). Henry Fairfield Osborn, Marcellin Boule and Aleš Hrdlička were the main players in a debate about whether Europe vs. Asia was the "cradle of Homo sapiens." This debate was largely centred around the connection between recent humans and Asian H. erectus versus European Neanderthals (Hrdlička, 1921; Woodward, 1922). Osborn was certain that Europe had been peopled from the east (Osborn, 1926), a view supported by Boule (Spencer \& Smith, 1981), while Hrdlička firmly maintained that Asia lacked any evidence of early humans, that present-day Asian populations had always been the inhabitants of the region, and that they showed no evidence of admixture with any outside groups (Hrdlička 1921). From this, he determined that the region had been peopled from southwestern Europe-his cradle of "mankind" -in part because the southern and eastern populations (his so-called Negritos and Malays) were too weak physically and mentally to have done so (Hrdlička 1921, p.537). In addition, Hrdlička pointed to the (then-believed) deep antiquity of the Heidelberg mandible and Neanderthal remains to further support the fact that Europe had the deepest roots of our species (Hrdlička, 1921, 1926). In doing so, he summarily rejected Osborn's Central Asia theory, along with Boule's belief that Neanderthals were an extinct side branch, and the general belief that our species had deep roots anywhere other than in southwestern Europe.

Hrdlička's commitment to the European origins of $H$. sapiens, and his scepticism that later, gracile Upper Paleolithic humans could have come from Africa or Asia, were profound enough that he rejected Black's interpretations of the Zhoukoudian fossils, considering them mere "Neandertalers" (Hrdlička, 1930). He ultimately proposed the "Neanderthal Phase of Man" to argue for a unilineal evolution of $H$. sapiens within Europe from Neanderthals, excluding the possibility of any outside contributions (Hrdlička 1927). Although he had very little support for his unilineal model (Spencer and 
Smith 1981), his focus on Europe as the unique birthplace of $H$. sapiens was shared by other prominent anthropologists of the day (Howell, 1957, Elliot Smith in Henke 2007; Keith, 1929). The emerging evidence relevant to recent human evolution from East and South Africa, as well as Southwest and Southeast Asia, was dismissed as unreliable (Smith and Spencer 1981) and the narrative of modern $H$. sapiens evolution did not shift its focus from Europe in a substantial way until the 1980s.

These examples from Africa and Asia illustrate the racist context in which our understanding of human origins arose. If our ancestry was found to be European-as was argued by Hrdlička, Keith and others-then Europe could be lauded as the source of modernness, with Africa and Asia considered more primitive (and incapable of producing modern people), and therefore marginalized, and deemed irrelevant in the narrative of human origins. But if our ancestry was found to be either African or Asian, then ironically those continents could still be portrayed as primitive, an act that served to maintain the relatively more evolved, modern status of Europeans. In addition, as we discuss in detail in the next section the simultaneous study of indigenous people in colonial contexts, the sourcing of their bodies for collections, and painting of them as primitive or wild (i.e., part of the local fauna), even as endangered species in need of protection (Sysling, 2015), served to further establish and reinforce a hierarchy. In essence, European scientists were actively placing Africans and Asians outside the definition of "real human," situating them as missing links between primitive fossil hominins and the more evolved living Europeans. In both scenarios, the othered, primitive identities of these continents and their people served to dehumanize them and maintain this status relative to the West.

\section{$19^{\text {th }}$ and $20^{\text {th }}$ century studies of the bodies of living peoples: models for "primitive" ancestors}

Throughout the $19^{\text {th }}$ and early $20^{\text {th }}$ century, as the fossil discoveries relevant to human evolution emerged and multiplied, concurrent studies of living human diversity rooted in a racist ideology were also being conducted. These aimed to support both the anatomical and psychological/intellectual superiority of white people over others (Gould, 1996; Sussman, 2014; Wolpoff \& Caspari, 1997). Physical anthropologists and researchers from cognate disciplines, including those who were themselves interested in human origins and hunting for fossil remains, were not just observers to this phenomenon, but were at the vanguard of these studies. These scientists were often directly engaged in body collecting and in research on living indigenous peoples-both physical and ethnographic-which they argued was for the purpose of understanding our more primitive ancestors and modeling what human 
ancestral hunter-gatherer societies might have been like (Fuchs, 2012; Gordon, 1992; Henderson, 2014; Kuljian, 2016). In other words, living people of colour were studied because they were believed to be less evolved, even less human, and thus to provide insight into our early ancestors (Perignuey 1915; Fabian, 2010; Gordon, 1992). This philosophy is most strikingly evidenced in how anthropological collections around the world were formed by the field's then-luminaries. Aleš Hrdlička, Samuel Morton, and Paul Broca, for example, viewed the bodies of non-whites as theirs for the taking, engaging in collection practices that included stealing bodies from burial places, battlefields, and hospital wards (Broca, 1865; Dias, 2012; Fabian, 2010; Hrdlička, 1904). European and North American museums and zoos began to collaborate with prominent scientists to include displays of living people from nonwestern societies, often called "human zoos."

The assistance that scientists provided in this treatment of living people as animals played out dramatically in Southern Africa, where the indigenous people referred to as "Bushmen" and "Hottentots," had been objects of scientific curiosity for decades. German anthropologist Eugen Fischer traveled to colonial Namibia to study the Herero and Nama peoples who had survived a German genocide and were imprisoned in concentration camps by Germany's Second Reich (these served as prototypes for the ones later used in the Holocaust) (Madley 2005). Fischer worked in conjunction with the National Socialist Party to conduct eugenic studies on mixed European-African children. These people were of particular interest for what they could reveal about the importance of keeping Europe "pure;" Southern Africans were widely seen as being of unique relevance for their primitive, perhaps even animal-like character (Madley 2005; Hambly, 1937). Many palaeoanthropologists even believed these populations might be the "missing link" between humans and apes (see Kuljian 2016 and references therein; Gordon 1992).

For that reason, Broom became a collector of "Bushmen" remains, often under dubious circumstances (Reader 1981). Dart's research interests also eventually expanded from fossils and bones to living people. The year after the Piltdown discovery was announced, a skull that came to be known as "Boskop Man" - literally bush-head man-was described by Broom as a possible ancestor to the "more or less degenerate Bushman" (quoted in Strkalj, 2000). Dart later took up this argument about the fossil and declared that living indigenous South Africans represented the ancestral stock from which humans were derived (Dart, 1925). Following that, he participated on expeditions such as the University of the Witwatersrand Kalahari Bushmen Expedition of 1936, where he and colleagues generated morphological data, photographs and face masks from local people to whom they gave nicknames or numbers (Kuljian 
2016). These masks continued to be made into the 1980 s by Tobias and form the Raymond A. Dart Collection of African Life and Death Masks, which numbers over 1000.

The morphological data taken on these expeditions included physical measurements such as head shape, but also gave special attention to the bodies of South African women, especially their genitalia. In fact, the earliest physical anthropology undertaken in South Africa, and the first academic interest in its inhabitants, centered on Khoe and San female genitalia (Cuvier, 1817; Galton, 1889). Dart's views, along with his contemporaries, and their work in the Kalahari were in keeping with the hyper-sexualized stereotypes about Africans that pervaded colonial science. This obsession with genitalia was not only an extension of ideologies from earlier Victorian times but also added a sexist element into the already racist exploitation of the native peoples (Gordon-Chipembere, 2011).

Perhaps the most profound example of the lasting effect that this sexist treatment of African bodies has had on palaeoanthropology is the fate of Sarah Baartman, the Khoe woman who had been brought to Europe and put on display in London and Paris as an example of a "living savage" in the early 1800s. After her death in 1816, Georges Cuvier created a plaster cast of her body, which went on display, along with her skeleton, in French museums until as late as the 1970s. Baartman had been given the nickname of "The Hottentot Venus," a name that invoked the Roman goddess of love (Scully \& Crais, 2008) but reduced her to a mere object, focusing entirely on her sexual organs and sexuality (GordonChipembere, 2011). At the same time, Upper Paleolithic female figurines were being uncovered in Hungary, Germany, and elsewhere in Central Europe, and described as fertility objects, having "exaggerated" breasts and buttocks. They were called "Venus" figurines in reference to Baartman's sexualized nickname (Fuchs 2012), connecting the primitiveness of Sarah Baartman to these prehistoric figures. The term "Venus figurines" continues to be used in academic publications on Paleolithic art despite critiques of its racist, sexist origin (Gindhart, 2008; White, 2006). All of this is illustrative of how in Africa the study of human origins has from the outset been inseparable from the study of "primitive people," and continues to be an extension of what has been playing out on the global stage for some time.

The commodification of bodies by the various Asian colonial powers was similar. In India, for example, the British administration viewed the adivasis, i.e., the so-called tribal populations who do not exist within the organized religious structure of Indian society, as the aboriginal inhabitants of India (Briggs, 1852; Crawfurd, 1868; Hodgson, 1848). They were thus taken as objects to be surveyed and studied scientifically as part of the wild landscape along with the flora, fauna, and geological formations 
(Pels, 1999) - much like the Africans had been studied as natural objects (Smith 1935; Hambly 1937). The British government set up formal offices such as the Geological Survey of India and Anthropological Survey of India to oversee the natural resources that were now possessed as part of the jewel in the empire's crown. In short, the bodies of Indians were objectified and studied by the British as part of taking inventory of their colonial possessions, and controlling their history ${ }^{1}$ (Pels, 1998, 1999).

In the Spanish, Portuguese, German, French, Italian and Dutch colonies, the commodification of colonized bodies was directly related to the growing science of anthropology in Europe and North America. There was a high demand for skeletal remains, especially skulls, from around the world (as also seen in Africa, see above), and major figures in the history of physical anthropology such as Paul Broca and Aleš Hrdlička let their needs be known to potential suppliers (Broca, 1865; Hrdlička, 1904). These included colonial administrators, explorers, doctors and especially members of the military who were instructed to collect bodies from hospitals, battlefields (after massacres from quelling uprisings or rebellions in the colonial states) and graveyards - all in the name of racial science (Dias, 2012; Roque, 2011). Roque (2011) compellingly argues that the demand for bodies from India, Indonesia, Macau, Timor, Taiwan, and other colonies throughout Asia and Oceania by British, French, Portuguese, Italian, German and Dutch scientists, was not simply to increase scientific knowledge about human variation. First, the bones were used by Broca, Topinard, Morton and others to "scientifically" demonstrate the racial ideologies of the day. And second, the agenda was also to recreate the Oriental's or African's history and identity through the lens of the white man. Museum curators were not just overseeing collections of bones, they were also actively constructing a new history for these populations as "savages," thus erasing or obscuring their humanity and history, and redefining them as "other," -as primitive representatives in "man's march towards civilization" (Roque 2011: 5).

\section{Transition to the current narrative of human origins: lingering effects of the colonial past}

The supporting role that scientists, including physical anthropologists, played in the colonial policies that contributed to the Holocaust led to a reckoning in the decades following the end of WWII. The eugenics movement that linked scientists with the genocidal actions of the Third Reich lost massive amounts of support in both the U.S. and Europe. Racist ideologies weren't entirely abandoned in

\footnotetext{
${ }^{1}$ An exception to this is China, where access to natural resources and collecting by foreigners was carefully controlled. For further reading on this, see Fa-ti Fan's British Naturalists in Qing China: Science, Empire and Cultural Encounter, Harvard University Press 2003.
} 
physical anthropology but were transformed, as evidenced by the publication of Carleton Coon's "Origin of Races" in 1962. There, he argued that the five purported races had deep roots in their respective geographical regions, and that Africans had crossed the threshold to modern humanity last, Europeans and Asians first. The implications were clear, and led to a complete programmatic revision for physical anthropologists, what Washburn (1951) called "the New Physical Anthropology." This saw a shift away from race-based typological studies and a focus on evolutionary processes. However, as Caspari (2003) has shown, essentialist and typological ideas remained embedded in paleoanthropology, reconfigured as the study of populations as clades.

In 1987, a seminal paper published in Science by geneticists Rebecca Cann, Mark Stoneking and Allan Wilson situated the root of the human species in Africa (Cann, Stoneking, \& Wilson, 1987). In spite of its typological framing of human evolution, it nonetheless appealed to a community of scholars eager to embrace a post-racial narrative by supporting an African root of humanness (e.g. Gould 1987, 1988 cited in Wolpoff and Caspari 1997; Caspari 2007). This paper also put the final nail in the coffin for the "pre-sapiens" and unilineal European models of Homo sapiens evolution of the previous six decades, and firmly shifted the narrative of recent human evolution to Africa. What emerged was a model that emphasized Africa as the source of humanity, with the original (modern) human female (because the research was based on mitochondrial data) cast by the popular press as "African Eve." Africa was no longer considered relevant primarily as a mere receptacle of primitive living people (and primitive extinct hominins), it was now the source of all humans. This fundamental shift from viewing Africa as the "other" to being central to all human identities was a major turning point in paleoanthropological narratives and had a wide-reaching effect. At the turn of the $21^{\text {st }}$ century former South African president Thabo Mbeki declared, "We are all Africans."

This new narrative was problematic, however, because it implicitly marginalized archaic Asians and Europeans (i.e., Neanderthals). A debate raged around which Pleistocene people, from which region, were our direct ancestors, and which were not. In the Out of Africa model, only the African lineage led to modern people, with early humans dispersing around the Old World and replacing other hominins who lived there. In other models such as the "Afro-European sapiens" hypothesis (Bräuer 1984), both Africa and Europe contributed to the origin of modern people. The Multiregional Evolution model was 
the most diametrically opposed to Out of Africa $^{2}$, and postulated that all regions contributed in some degree to the evolution of Homo sapiens (Wolpoff, Wu, \& Thorne, 1984). This model had emerged earlier out of observations made by Australasian scholars regarding evolutionary phenomena in their parts of the world (e.g. Thorne, 1981; Wu, 1988), and was a reconfiguration of the trellis model that Weidenreich had developed decades earlier (Weidenreich 1948). Throughout the 1990s, the so-called "modern human origins debate" dominated Late Pleistocene studies in paleoanthropology, frequently making news headlines and becoming canon in anthropology textbooks. The intensity and staying power of the debate reflects a certain intellectual stagnation in paleoanthropology-nearly 30 years later, discussions of $H$. sapiens evolution are still framed as being part of this debate.

The Out of Africa model was ultimately more widely accepted and has dominated the literature over recent decades; its success has as much to do with the sociopolitical dimensions of paleoanthropology as the actual data (Wolpoff and Caspari 1997; Caspari 2007). It has come to be defined by a set of "facts," which although taken as universally agreed upon, are open to debate and carry echoes of colonialism and western superiority. First, humans are said to have a single origin in a single location, often referred to (even in scientific publications) in Biblical terms. This single population was supremely successful, and alone had the flexibility and adaptability to disperse throughout the globe replacing existing "archaic" groups. Second, so-called "archaic" groups were not modern, by definition; they were implicitly less able, backwards, stagnant, or on the verge of extinction. Although the population history of our origins has been argued on the basis of fossil morphology to be more complex than this (e.g. Caspari \& Wolpoff, 2013; Trinkaus, 2005; Wu, 2004), and genetic studies have supported these assertions (e.g. Fu et al., 2015; Fu et al., 2013; Templeton, 2002), nonetheless these narratives persist.

Within the Out of Africa narrative of $H$. sapiens evolution, the Asian data continue to be cast within an Orientalist framework. The cradle of $H$. sapiens, once to be found in the Swanscombe or Piltdown fossils from northwestern Europe, is now believed to be in Africa, while the Zhoukoudian and Ngandong fossils are seen as dead ends (or at best, being on the evolutionary trajectory of living East Asians and Australians respectively). With few exceptions, East Asia is seen as an irrelevant player in the evolution of extant $H$. sapiens-possibly (in certain formulations) a recipient of unidirectional west-to-

\footnotetext{
${ }^{2}$ Although both models have changed over time in terms of how much they have emphasized gene flow, dispersals, migration, and neutral evolution, we are concerned with the ways in which they fundamentally differ in how they viewed African and Asian hominins. Out of Africa sees "modern humans" as a singular entity with an African origin; Asian populations are marginal and archaic. Multiregionalism questions the essentialist concept of "modern" human, the singular origin in Africa, and the marginality of Asian populations.
} 
east migrations but not a producer of genetic innovation or modernity for the Western world. This continues to reflect a view of East Asia that has persisted since colonial times of a region that is remote, isolated, closed off and inaccessible (J. Darwin, 2008). It has been cast for the past 80 or so years as (in Movius's words) a marginal region of "cultural retardation" (Movius, 1948, p. 411) that had made very little contribution to humankind.

Today, scientists continue to echo the colonialist mindset, not only viewing Asian Homo erectus itself as stagnant, but also Asian research as ethnocentric and therefore irrelevant to current models of human evolution (see Qiu, 2016). Models developed from within the region, such as Wu's "continuity with hybridization" (Wu 1988, 2004) have been overlooked entirely. The recent embrace of a narrative of human evolution that entails both a measure of continuity and hybridization (e.g. Ackermann et al. 2016; Galway-Witham and Stringer 2018) has largely occurred because of scientific observations and interpretive models developed by Western researchers; the current discourse contains little or no mention of the non-Western scholars who have been making similar observations based on their own data for decades. So while the data from Asia and other marginalized regions are now given authority within the human origins story-a seemingly progressive development-no authority is actually given to the scientific observations or interpretive models developed by scholars from those regions. That authority remains exclusively in the hands of Western scientists.

In addition, as with original models of human origins, current studies continue to fall back on the notion that living Africans-hunter-gatherers in particular-are appropriate primitive models for early humans. While a few critiques of this assumption exist (Kelly, 2013; Schrire, 1980; Testart et al., 1988) for the most part, prehistorians have not critically examined the colonialist elements of the "Man the Hunter" model. The implicit assumptions of evolutionary primitiveness that accompany these studies are perpetuated by recent high-profile research on African societies within the framework of human evolution. These studies compare Africans including Ju/ 'hoansi and Hadza-and indeed several foraging societies from colonized countries-to apes in order to determine the "deep social structure of humankind" (Chapais, 2011, 2013; Hill et al., 2011). Similarly, a recent feature article in Science portrayed the Hadza as subjects of study precisely for the insight they give into human evolution.

"Times are hard for the Hadza, who include some of the last people on the planet to live as nomadic hunter-gatherers. Their way of life has been a magnet for researchers for 60 years, and the subject of hundreds of scholarly papers, because it may offer the closest analog to the way our African ancestors lived." (Gibbons, 2018, p. 700) 
The article also included references to their drunkenness, a dead baby, diarrhea, and other indicators that they are not capable of modernity. Living hunter-gatherers are often treated as having social structures that have remained unchanged since the early days of human evolution, and thus serve as effective telescopes to our past, despite the fact that these societies have been reconstituting themselves and their organizational rules for thousands, if not tens of thousands of years (Appadurai, 1988; Kopytoff, 1987). These assumptions of primitiveness and stagnation have been present since the earliest contact between Europeans and Africans and served as the basis for imperial policy (Mudimbe 1994).

The Out of Africa/Replacement narrative also carries imperialist overtones, as portrayed in both the popular press and in scientific publications. For example, recently in both Scientific American and Journal of Human Evolution, paleoanthropologist Curtis Marean (Marean, 2014, 2015a) modeled Homo sapiens evolution and dispersals as being the product of one African population's unique intellectual superiority coupled with their advanced weaponry and hyperprosocial behavior (i.e., hyper-ingroup cooperation/outgroup hostility). Upon dispersing with this advanced bio-behavioral repertoire, they encountered archaic populations with whom they engaged in territorial conflicts and ultimately whom they replaced. Marean describes this process:

“...[M]odern humans were equipped to respond to any environmental crisis with flexible social connections and technology. They became alpha predators on land, and, eventually, sea. This ability to master any environment was the key that finally opened the door out of Africa and into the rest of the world... Archaic human groups that could not join together and hurl weapons did not stand a chance against this new breed..." (2015a, p. 9)

In his response to reader comments on the male-centric nature of his model, Marean stated in his online post:

"Such events are penetrating, brutal, bloody affairs, and the killing and butchery that ensue is the product of weapons and men." (Marean, 2015b)

In sum, and based on previous work arguing the same (e.g. Bowles, 2009; Bowles \& Gintis, 2011), the story of human history is that we are inherently conflict-oriented and programmed to "otherize" members outside our group and that this violent nature, along with our intellectual and technological superiority, is largely the domain of men, and is what ultimately led to our success as a species.

This retelling of European colonial expansionism in biological terms presumes that populations that had been living in Eurasia for over a million years were less well-adapted to their own environments. Indeed, the Out of Africa narrative, in general, perpetuates the view that one group is 
adaptively superior to another. Even within Africa, much of the debate has focused on which region can claim to be the root of living people, once again, the implication being that a single population of Africans had superior capabilities, cognitive or otherwise, that alone made it superior to other Africans (but see Hublin et al., 2017; Scerri et al., 2018). As above, modern human origins research often neatly packages this narrative of success with male domination and violence at its core-echoing imperialist models of bloody expansionism over inferior groups. The imagery associated with human origins research often powerfully captures this male-dominated, violent and racially charged space, both through the ubiquitous portrayal of humans evolving into a white man, often with weapons (Fig. 1), and representations of Africans as violent, virile, and primitively clad (Fig. 2). Additionally, these depictions invariably collapse numerous complex temporalities into a small number of actors, locations, and characteristics in service of a single narrative strand.

As this discussion shows, the frameworks of Orientalism and African primitivism still pervade today's studies of human evolution. The narrative that has come to dominate human origins research is still drenched in a notion of superior groups, superior intelligence or capabilities, that draws from the Western views (and racist ideologies) of the past. These capabilities are also constructed to be universal and transcendental, a part of humanity's essential characteristics. Africa is now our primordial home, the site of, as Kim TallBear says, the "biogeographical pinpoint of originality." (TallBear, 2013, p. 6). Geneticists trying to reconstruct our past now look to study "unadmixed" native populations (a genetic impossibility); Western scholars still treat living groups from former colonies as fossils from the past, and still impart notions of biological purity into their studies. What is ironic is that the Africans are, by definition, the most successful in this narrative (because humans emerged from Africa) and yet remain primitivized.

\section{[Insert Figures 1 and 2 about here]}

\section{Orientalism, Afrocentrism, and the practice of paleoanthropology today}

These examples serve as good mirrors in which to reflect on the discipline of paleoanthropology and its lingering biases. On the whole, they show that today's framing of Africa and Asia in paleoanthropological narratives is not terribly different from what Saïd and Mudimbe described. The continued owning, shaping and defining of the meaning of Asian and African identities is part of the 
legacy that both scholars wrote about. The early focus on Asia as the cradle of human ancestry took place in a decidedly Orientalist context. Saïd (1978) noted that European culture managed, and even produced, the Orient-politically, sociologically, militarily, ideologically, and scientifically. The idea that an entity known as "the East," existed in contradistinction to "the West," was consciously and deliberately constructed by European scholars, politicians and philosophers over the course of the $18^{\text {th }}$ $20^{\text {th }}$ centuries (Saïd 1979). By engaging in this discourse, Europeans were both implicitly and explicitly asserting that Asia was an unknown entity that needed to be explained, understood and defined-and they did so in European terms.

Likewise, Mudimbe noted that "The Savage Man" of Africa was a "brilliant invention of the $14^{\text {th }}$ and $15^{\text {th }}$ centuries which preceded (and shaped) the western 'discovery' of savages $\ldots$ in the $16^{\text {th }}$ century" (1994, p. 8). During the early decades of paleoanthropology when the focus was on our Asian roots, Africa was relegated to a mere side-note, believed to have neither lithic nor fossil remains and therefore to play no role in human evolution at all (Smith, 1935). This perception was consistent with the belief that the continent was a blank slate (terra nullis; Mudimbe 1994), which was essential to justifying colonial policies there. It was within this construction that our origins stories emerged.

Today's narrative sees Africa as centralized and Asia marginalized in our evolutionary origins; at other times, the inverse was true. Regardless, in the face of changing fossil, archaeological and genetic evidence, and shifting global dynamics and interests, the superiority of Westerners was maintained, and Asians and Africans othered. Initially this was an active attempt at centering Europe in the story of human origins, but as evidence percolated out that countered this hypothesis, power relations were maintained through other means. As argued above, in the case of Africa, the continued characterization of Africans as primitive allowed Western researchers to simultaneously position Africa as the continent of origin while retaining Europeans as the "civilized" group. They also framed the dynamics in the context of superior abilities and domination, a decidedly Western, colonialist slant. In the case of Asia, what was originally considered the most likely source for human ancestors has now been cast as an evolutionary backwater. The point is that no matter how the science plays out, the narrative that emerges always leaves one group in control, and marginalizes non-European lands and their peoples.

Beyond the realms of academia, palaeoanthropological policies and practices of the last century and a half have had lasting impact on people outside the discipline, especially people descended from populations who have been othered, managed, or produced. It has perhaps most dramatically reared its head in policy disputes around repatriation and museum displays. These disputes highlight an important 
connection between our human origins narrative, racism and the public perception of our science. As Ros Langford eloquently pointed out (1983), we continue to study people (and their ancestors) as objects, using their bodies, defining their histories, and often taking issue with societies wanting to control their own narratives (Morell, 1995; Murray \& Allen, 1995).

Most recently this issue has surfaced in the heated discussion by paleoanthropologists over the repatriation and reburial of the Kow Swamp and Lake Mungo Australian remains, Kennewick Man from the Pacific Northwestern U.S., Tasmanian Pleistocene data (Dumont, 2003; Fforde, Hubert, \& Turnbull, 2004; McNiven \& Russell, 2008), and the Zambian government's request to UNESCO to return the Kabwe skull which had been immediately taken to Britain in 1921 upon its discovery (Government of the Republic of Zambia, 2016). In a South African context, the scientific primitivization of indigenous groups has also received push-back. As a result, in August 2013, a decision was made to place all "Bushman" life casts on display at the Iziko South African Museum in Cape Town in permanent storage (Schramm, 2016). Nevertheless, following the 2015 announcement of the new species Homo naledi, it became clear that this linking of black people and primitiveness through the medium of paleoanthropology still persists in the mind of the public; popular depictions linked black people-especially black leaderswith this hominin ancestor, suggesting that they were somehow less evolved (Figure 3).

Today's paleoanthropologists often continue to marginalize the voices and experiences of nonWestern peoples in the name of scientific inquiry which they see as unassailably objective. As Lori Hager writes:
"Based on the principles of the scientific method, "scientific" interpretations are expected to be more than "just stories." They are intended to be the most logical, plausible, and objective explanations of the observable facts. And because paleoanthropology conducts its research within the realm of "science," it is often assumed that it is objective and bias-free ..." (Hager, 1997, p. 3, emphasis added).

Hager goes on to argue that, on the contrary (and like all sciences), paleoanthropology is neither objective nor bias-free. This may come as some surprise to scientists, who tend to think of themselves as isolated from their socio-political context. This manifests itself in the notion that Western scientists engage in "pure" science, and must avoid "identity politics". But for palaeoanthropologists, denying the inherent hegemonic context in which they are producing knowledge means ignoring the power they have to shape what are considered the "facts" surrounding the identities and histories of others, as well as the responsibility they have to make space for these marginalized voices. 


\section{[Insert Figure 3 about here]}

These examples convey how colonial ideas of owning, otherizing and primitivizing non-European cultures, minds and bodies, illustrated by Saïd and Mudimbe, have persisted into the present. We argue that this is primarily a reflection of the fact that scientists from former colonial countries continue to control who shapes the narrative of the human past. This persistent control is due in large part to the demographics of the field (e.g. few non-Western people on high profile science projects or serving as lead authors), as will be discussed further below. Moreover, while some other branches of anthropology engage in reflexive post-colonial critiques with respect to the issue of voice, representation and power (Pels, 2008), paleoanthropology has yet to do so in any meaningful way (but see Porr \& Matthews, 2017). Without a reflection on the field's colonialist history, researchers continue to present these histories defined in colonial terms, implicitly (if inadvertently) reinforcing the notion that dark-skinned people are less human.

This lack of reflexivity is in part a direct outgrowth of the way science is viewed in Western societies, where scientists are the sole keepers of global knowledge (see Dumont 2003). Indigenous people's ways of knowing, their desire to control their own bodies or representation, or to define their histories, are not considered objective. The scepticism towards non-Western knowledge construction is played out in many paleoanthropological field sites and laboratories in Africa, where the field workers and technicians are not white, and the team leaders are primarily well-funded European or American researchers from abroad who, by controlling the financial resources, also control the production of "facts."

This hierarchy of knowing has also been expressed in the dismissal of narratives of human evolution constructed by Asian paleoanthropologists working in countries that have long and distinguished histories of paleoanthropological research in their own right. The Orientalist framework, in which the "East" was cast as irrational, unvirtuous, and childlike (Saïd 1978) is still a part of paleoanthropological science, which situates the region as a remote, stagnant evolutionary backwater with little to contribute to understanding human origins. For example, between 1950 and 2004 there was not a single session on human evolution in Asia at the annual meetings of the American Association of Physical Anthropologists. Between 1984 and 2004, the majority of research and popular news stories about human evolution in Asia centered around the stagnation of $H$. erectus there for two million years. Asian scholars who questioned this interpretation were dismissed as "biased" and therefore not 
trustworthy (see quotes in Qiu 2017). That the same ethnocentric biases characterize western paleoanthropology seems to go unremarked.

Our goal here has been to demonstrate the ways in which paleoanthropology has developed ideologically out of a colonialist past. The data, models, assumptions, and practices are all legacies of a racist agenda, centered around "otherizing" and dehumanizing non-western peoples. There are remarkably few African and Asian scholars at the forefront of our field, shaping the narrative of human evolution for global consumption. And, unlike other branches of anthropology, our subfield has not truly undergone a critical re-examination of its roots. As a result, scholars in our field are largely a demographically homogenous group, inadvertently perpetuating practices that continue to otherize and marginalize African and Asian bodies and ideas. The dangers of this should be self-evident. Not only has the lack of diversity and inclusivity in our field reduced the level of excellence and innovation overall; but it has also actively, albeit unintentionally, contributed to the racist agendas on which our field was built.

\section{A way forward: Reimagining a new narrative of human origins}

Paleoanthropology is a historical science, and cultural bias is inevitable in historical reconstructions. The problem, as Hager noted above, is that western paleoanthropologists tend to view their science as ahistorical-as a mere uncovering of objective facts, free of any observer or implicit bias (Henke 2007). Western paleoanthropologists have yet to fully embrace their part in owning and shaping "otherized" bodies. As a result, the effects of the discipline's historical legacy play out at every level of our work. Western paleoanthropologists are the primary definers of the questions asked, based on our own a priori assumptions (such as, there is a single entity, "modern human," that has a single origin with a single behavioral repertoire in Africa). Western paleoanthropologists, by and large, define the units of analysis ("aborigines", "Africans", etc.) and determine what roles these communities can play in shaping the scientific narrative (Marks, 2001). Ultimately Western paleoanthropologists control whose voices are given authority, and who gets to story the history of humanity.

What would a different conceptualization of human evolution studies look like, outside of this postcolonial legacy described by Saïd and Mudimbe? We propose two primary ways that our field can engage in new approaches to constructing the narrative of human origins that will deal constructively with the issues discussed above. Both revolve around the integration of other voices and peoples into 
the framing of the questions, because the lack of diverse representation and diversity of voices in paleoanthropology leads to the perpetuation of stereotypes embedded in our scientific models, often subconsciously, as we have alluded to throughout this chapter.

First, we need to embrace a more complex conceptualization of the evolutionary mechanisms behind human origins, where regional groups cannot-and should not-be parceled into discrete units, and where no single region dominates. This includes abandoning the search for the "first." The Out of Africa narrative of $H$. sapiens evolution that we discussed above is, at its heart, an adaptationist approach to considering the production of diversity. Adaptationist approaches are nearly ubiquitous in paleoanthropology generally, despite our understanding that divergence and differences among human groups and hominin taxa frequently occur without adaptation at all (Ackermann \& Cheverud, 2004; Schroeder \& Ackermann, 2017; von Cramon-Taubadel \& Weaver, 2009; Weaver, Roseman, \& Stringer, 2007). In the Out of Africa model, Africans evolve first into modern people, and it is only the African lineage that leads to modern humanity, replacing other hominins. This implies that a single group evolved special traits that provided a fitness advantage-either culturally or biologically-over those they replaced. It is an argument of domination and superiority-products of a western colonial mentality. The winners are seen as better adapted (or phrased differently evolutionarily "superior") to whatever environmental context they were in, or moved into, than the other hominins on the landscape-a retelling of European colonial views of economic exploitation and efficiency (Porr 2014). Even when gene flow is recognized in this model, the questions are still being framed in terms of purity and impurity, evolutionarily superior to inferior, and relative success.

This whole framing of the human origins narrative as one of discrete (and adaptively different) groups that migrated, replaced or admixed reifies meaningful groups differences and hierarchies among these groups (whether recognised as populations/races or species; see Terrell, 2018). It is a model that developed out of a colonialist worldview. A more complex and scientifically appropriate understanding of human history as reticulating networks that was not built on these constructs has been discussed for decades by researchers from eastern Eurasia and Oceania, and these should be brought more into mainstream discussions. These models address the role that complex (biological, cultural) processes and individual/regional diversity have played in shaping our evolutionary trajectory.

In Western science, an increasingly complex narrative around human origins is finally recognizing this, although it often falls back into the same superior/inferior narrative framework as before. Nonetheless, the research is at last embracing the idea that multiple groups both within and 
outside of Africa contributed to the human lineage (e.g. Green et al., 2010; Kuhlwilm et al., 2016). In addition to being more inclusive, this acknowledgment of the importance of local processes is forcing western scholars to challenge what it means to be anatomically and behaviourally "modern" (e.g. Ackermann, Mackay, \& Arnold, 2016), which will in turn provide the intellectual space for researchers to unpack the extent to which western ideology has constructed modernness. However, this research typically fails to cite the Asian and Australian scholars who have been proposing these ideas for decades, instead attributing these "new" ideas to the work being done by Europeans and North Americans. As we will further outline below, giving a greater platform to marginalized scholars such as these, to their studies and their models, is an important element to re-invigorating the science of paleoanthropology.

Second, we need to abandon the representation of early humans as primitive in a way that directly links this primitiveness to living people today. This representation is pervasive, from modern human origins research to museum displays to the public imagination. It reifies races and racism in a way that is damaging to the prospects of paleoanthropology as a viable discipline. It has no doubt played a primary role in keeping people from entering the discipline, and is a major contributor to the crisis of repatriation. Dismantling this legacy can be achieved through many means, including outreach, curriculum re-development, and implicit bias training. But it is perhaps best-and most rapidlyachieved by increasing representation from marginalized groups in the primary research itself. It is well established that diverse teams result in better science (Apfelbaum, Phillips, \& Richeson, 2014; Freeman \& Huang, 2014; Hong \& Page, 2004). The last century and a half of modern human origins research has been exemplified by the production of knowledge by a privileged-and very homogenous-few. Efforts at diversifying the field in the United States have resulted in bodies such as the Committee on Diversity in the American Association of Physical Anthropologists (Antón, Malhi, \& Fuentes, 2018). While this is creating an important pipeline of scholars from underprivileged communities in the U.S., it addresses only part of the problem. True inclusivity must provide a safe and equal platform for a wide range of voices that have historically been gate-kept from scientific space. This means publishing research by scholars from the Global South, from poor countries, and from non-western countries that have long histories of paleoanthropological research. Many of these communities engage in science and knowledge construction differently than our hypothetico-deductive model, but their facts are no less well-vetted, falsifiable or repeatable.

Non-Western scientists also bring different assumptions and framings about the past and the present into the science itself, and their value systems need to be represented in order to improve the 
quality of our models. Chinese, Indian, and Australasian scientists, for example, so frequently dismissed as "biased" and "ethnocentric" have a better understanding of the unique regional processes that have shaped populations in East, South, and Southeast Asia, and Australia; that understanding should be equalized as valid in our scientific literature. African scientists-woefully underrepresented as authors on paleoanthropological research in Africa-should be equal partners in all stages of scientific research, from constructing research questions to participating in the study design to being given lead-author control and authority over how publications resulting from the research disseminate information. And African participants in paleoanthropology more generally should be acknowledged in official publications beyond their contributions as technicians, field workers, fossil finders and unsung heroes (e.g. leakeyfoundation.org/category/fossil-finders/).

At all levels of decision making in science-in journal article reviews, grant reviews, paper authorship, and promotion letters-colonial value systems dominate. It cannot, therefore, come as a surprise-given that the people framing the questions and leading the research for the past century and a half share a common heritage, outlook and value system - that the narrative of human origins has been heavily influenced by confirmation bias (see Page, 2007). By decolonizing our science and making space for the voices of people who have historically been the objects of study-the "other"-our narratives can more inclusively reflect how humanity views itself and its history. Incorporating a wider diversity of value systems and outlooks will go a long way towards correcting the problematic narratives of the past, ultimately leading us closer to the truth of our common origins. 


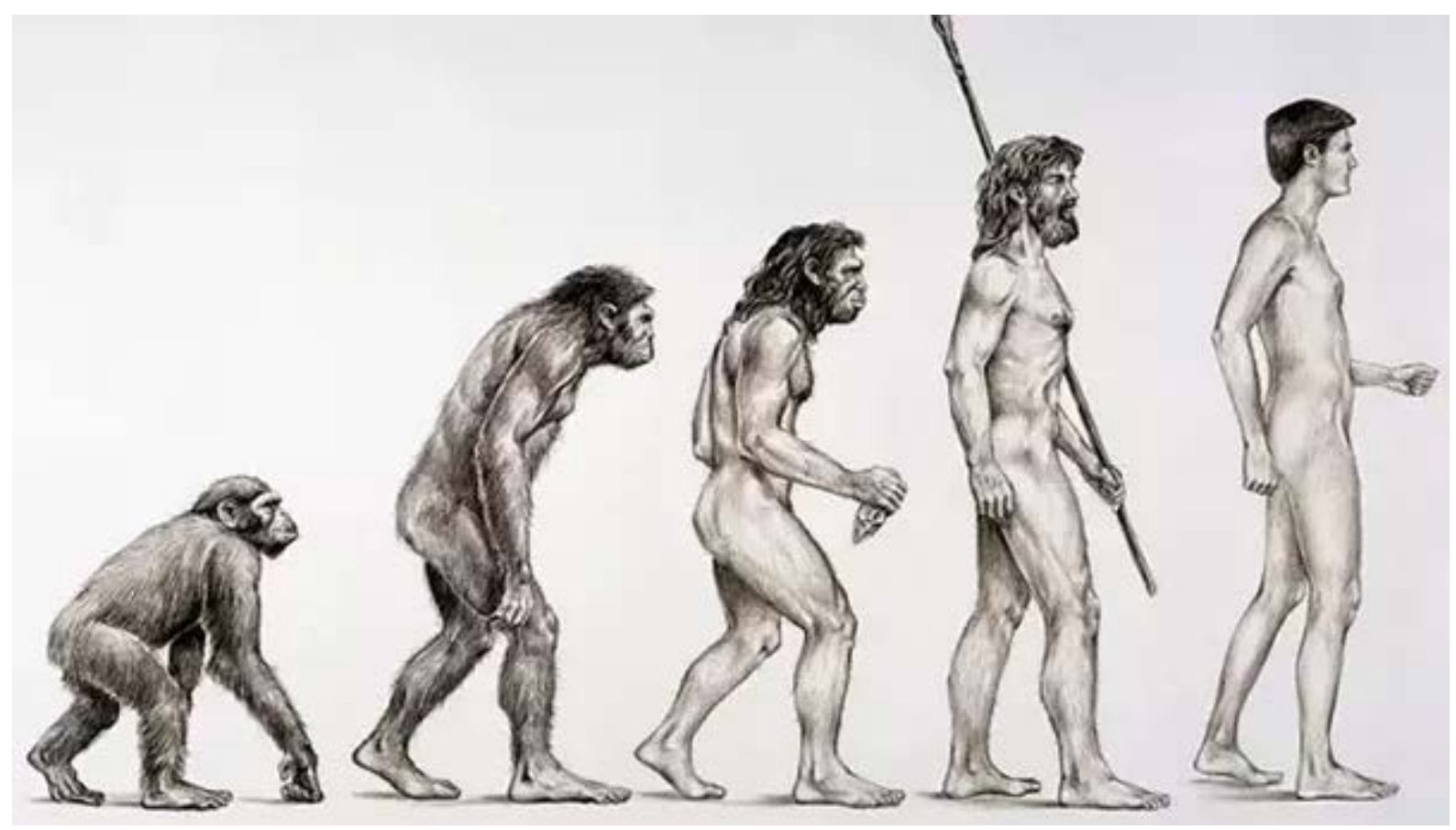

Figure 1. A common (ubiquitous) portrayal of the evolution of humans from an ape to a modern white man. "Evolution of Man" by Corbis. 


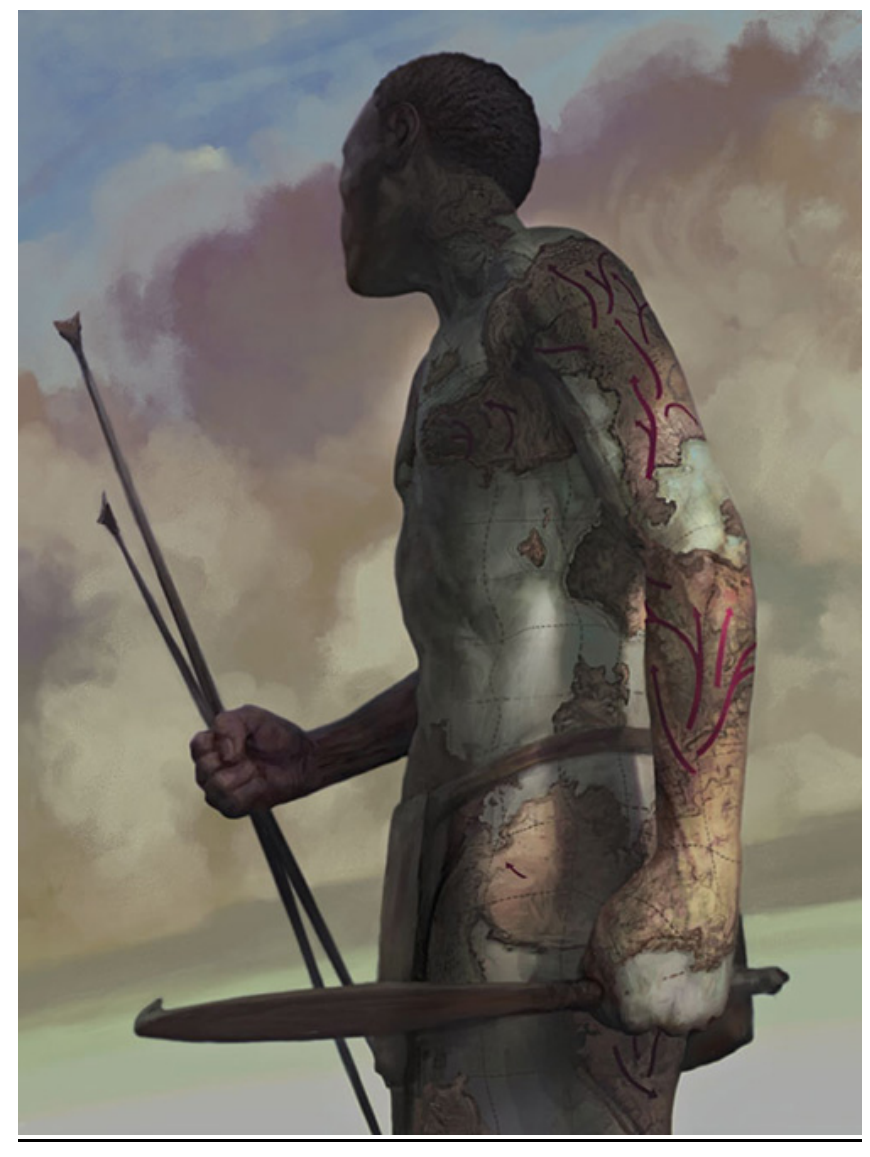

Figure 2. Artistic representation of the first humans. From Marean $2015 a$ 


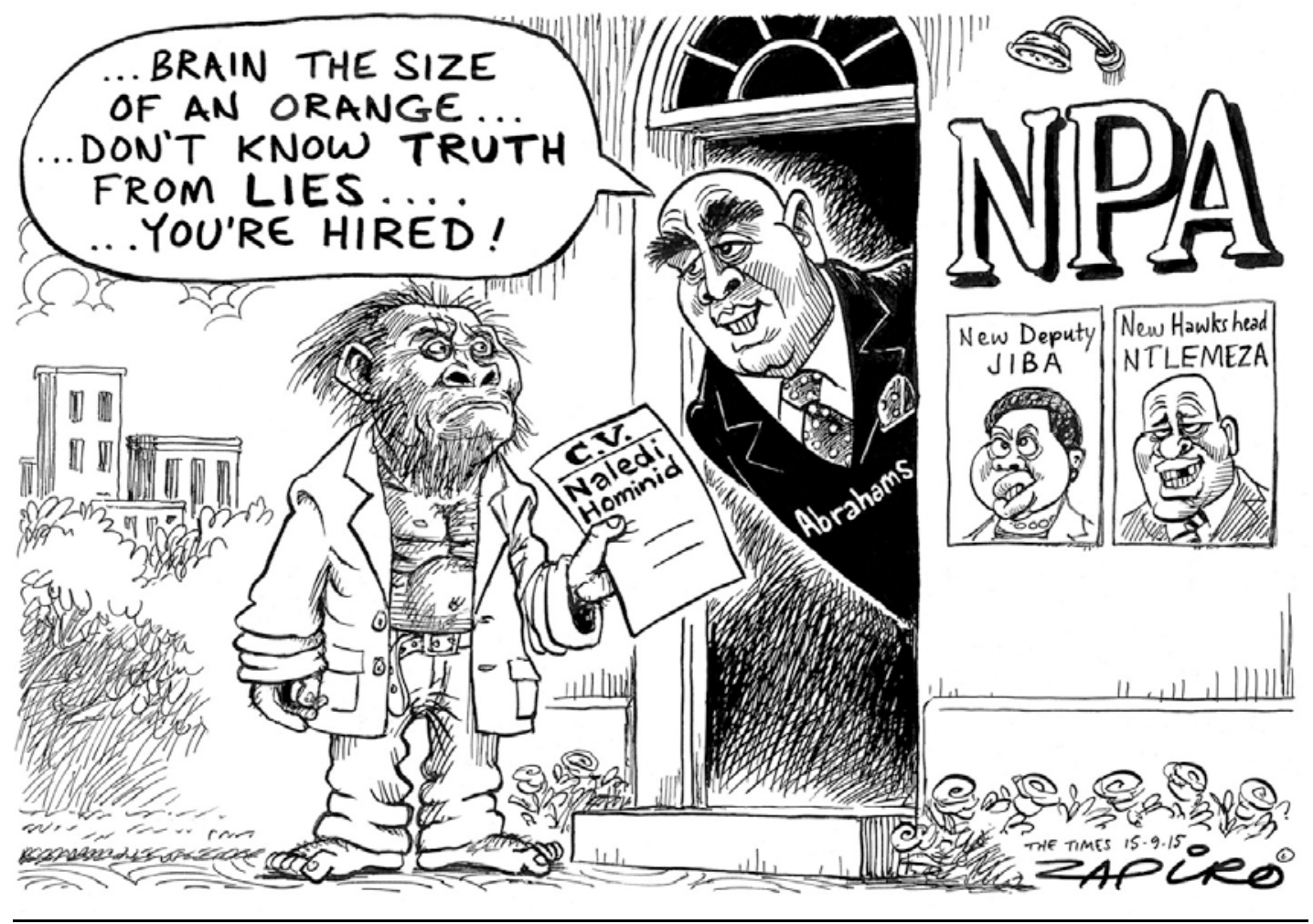

Figure 3. Cartoon run in South African newspapers explicitly links Homo naledi and living black members of the National Prosecuting Authority as a commentary on their intelligence and abilities. Cartoon by Zapiro, The Times (C) 2015. Re-published with permission. 


\section{References}

Ackermann, Rebecca Rogers, \& Cheverud, James M. (2004). Detecting genetic drift versus selection in human evolution. Proceedings of the National Academy of Sciences, 101(52), 17946-17951.

Ackermann, Rebecca Rogers, Mackay, Alex, \& Arnold, Michael L. (2016). The hybrid origin of "modern" humans. Evolutionary Biology, 43(1), 1-11.

Antón, Susan C, Malhi, Ripan S, \& Fuentes, Agustín. (2018). Race and diversity in US Biological Anthropology: A decade of AAPA initiatives. American journal of physical anthropology, 165, 158-180.

Apfelbaum, Evan P, Phillips, Katherine W, \& Richeson, Jennifer A. (2014). Rethinking the baseline in diversity research: Should we be explaining the effects of homogeneity? Perspectives on Psychological Science, 9(3), 235-244.

Appadurai, Arjun. (1988). Putting hierarchy in its place. Cultural Anthropology, 3(1), 36-49.

Athreya, Sheela. (2017). Dead end evolutionary lineage, says the White man: the evolution of Homo erectus and Homo sapiens in Asia. Paper presented at the 86th Annual Meeting of the American Association of Physical Anthropologists.

Bowles, Samuel. (2009). Did warfare among ancestral hunter-gatherers affect the evolution of human social behaviors? Science, 324(5932), 1293-1298.

Bowles, Samuel, \& Gintis, Herbert. (2011). A cooperative species: Human reciprocity and its evolution. Princeton, NJ: Princeton University Press.

Bräuer, Gunter. 1984. "The "Afro-European sapiens hypothesis," and hominid evolution in East Asia during the late Middle and Upper Pleistocene." Courier Forschungsinstitut Senckenberg 69:145165.

Briggs, John. (1852). Art. XIII.-Two Lectures on the Aboriginal Race of India, as distinguished from the Sanskritic or Hindu Race. Journal of the Royal Asiatic Society, 13, 275-309.

Broca, Paul. (1865). Instructions générale pour les recherches anthropologiques (Anatomie et physiologie). Paris: V. Masson et fils.

Cann, Rebecca L., Stoneking, Mark, \& Wilson, Allan C. (1987). Mitochondrial DNA and human evolution. Nature, 325, 31-36.

Caspari, Rachel. 2003. "From Types to Populations: A Century of Race, Physical Anthropology, and the American Anthropological Association." American Anthropologist 105 (1):65-76.

Caspari, Rachel. 2007. The "Out of Africa" hypothesis. In The Encyclopedia of Race and Racism, edited by Moore JH. Detroit: Gale (MacMillan Reference, USA): 391-397.

Caspari, Rachel, \& Wolpoff, Milford H. (2013). The process of modern human origins: the evolutionary and demographic changes giving rise to modern humans. In Fred Smith \& James Ahern (Eds.), The Origins of Modern Humans: Biology Reconsidered (pp. 355-392). Hoboken: John Wiley and Sons.

Chapais, Bernard. (2011). The deep social structure of humankind. Science, 331(6022), 1276-1277.

Chapais, Bernard. (2013). Monogamy, strongly bonded groups, and the evolution of human social structure. Evolutionary Anthropology: Issues, News, and Reviews, 22(2), 52-65.

Crawfurd, J. (1868). On the Supposed Aborigines of India as Distinguished from Its Civilised Inhabitants. Transactions of the Ethnological Society of London, 6, 59-71. 
Cuvier, Georges. (1817). Extraits d'observations faites sur le cadavre d'une femme connue à Paris et à Londres sous le nom de Vénus Hottentot'. Mémories du Muséum d'Histoire Naturelle, 3, 259274.

Dart, Raymond A. (1925). The present position of anthropology in South Africa. South African Journal of Science, 22(11), 73-80.

Darwin, Charles. (1871). The Descent of Man and Selection in Relation to Sex. London: John Murray.

Darwin, John (2008). After Tamerlane: The Global History of Empire Since 1405: Bloomsbury Publishing USA.

Dennell, Robin. 2018. "Where evolutionary biology meets history: ethno-nationalism and modern human origins in East Asia." In Rethinking Human Evolution, edited by Jeffrey H. Schwartz, 229250. Cambridge, MA: MIT Press.

Dias, Nélia. (2012). Nineteenth-century French collections of skulls and the cult of bones. Nuncius, 27(2), 330-347.

Dumont, Clayton W. (2003). The politics of scientific objections to repatriation. Wicazo sa review, 18(1), 109-128.

Fabian, Ann. (2010). The Skull Collectors: Race, Science, and America's Unburied Dead: University of Chicago Press.

Fforde, Cressida, Hubert, Jane, \& Turnbull, Paul. (2004). The Dead and their Possessions: Repatriation in Principle, Policy and Practice (Vol. 43): Psychology Press.

Freeman, Richard B, \& Huang, Wei. (2014). Collaboration: Strength in diversity. Nature News, 513(7518), 305.

Fu, Qiaomei, Hajdinjak, Mateja, Moldovan, Oana Teodora, Constantin, Silviu, Mallick, Swapan, Skoglund, Pontus, et al. (2015). An early modern human from Romania with a recent Neanderthal ancestor. [Letter]. Nature, 524(7564), 216-219.

Fu, Qiaomei, Meyer, Matthias, Gao, Xing, Stenzel, Udo, Burbano, Hernán A., Kelso, Janet, et al. (2013). DNA analysis of an early modern human from Tianyuan Cave, China. Proceedings of the National Academy of Sciences, 110(6), 2223-2227.

Fuchs, Brigitte. (2012). 'Bushmen in Hick Town': The Austrian empire and the study of the Khoesan. Austrian Studies, 20, 43-59.

Galton, Francis. (1889). Narrative of an Explorer in Tropical South Africa: Being an Account of a Visit to Damaraland in 1851 (Vol. 2): Ward, Lock and Company.

Galway-Witham, Julia, and Chris Stringer. 2018. "How did Homo sapiens evolve?" Science 360 (6395):1296-1298. doi: 10.1126/science.aat6659.

Gibbons, Ann. (2018). Hadza on the brink: American Association for the Advancement of Science.

Gindhart, Maria P. (2008). Cro-Magnon and Khoi-San: Constant Roux's racialized relief sculptures of prehistoric artists. Visual Resources, 24(3), 321-342.

Gordon, Robert J. (1992). The venal Hottentot Venus and the great chain of being. African Studies, 51(2), 185-201.

Gordon-Chipembere, Natasha. (2011). Representation and Black Womanhood: The Legacy of Sarah Baartman: Springer.

Gould, Stephen Jay. (1996). The Mismeasure of Man (Revised and expanded ed.). New York: W.W. Norton and Company. 
Green, Richard E., Krause, Johannes, Briggs, Adrian W., Maricic, Tomislav, Stenzel, Udo, Kircher, Martin, et al. (2010). A draft sequence of the Neandertal genome. Science, 328(5979), 710-722.

Gregory, William King. (1927). Did man originate in Central Asia? (Mongolia the New World, Part V). The Scientific Monthly, 24(5), 385-401.

Gregory, WIlliam King, \& Hellman, Milo. (1938). Evidence of the Australopithecine man-apes on the origin of man. Science, 88(2296), 615-616.

Haeckel, Ernst. (1876). The History of Creation. On the Development of the Earth and Its Inhabitants by the Action of Natural Causes; a popular exposition of the doctrine of evolution in general, and of that of Darwin, Goethe, and Lamarck in particular (E.R. Lankester, Trans. 2nd ed.). London: Henry S. King \& Co.

Hager, Lori D. (1997). Sex and gender in paleoanthropology. In Lori. D. Hager (Ed.), Women in Human Evolution (pp. 1-28). London, New York: Routledge.

Hambly, Wilfrid D. (1937). Source Book for African Anthropology: Part II. Publications of the Field Museum of Natural History. Anthropological Series, 26(2), 407-953.

Henderson, Carol E. (2014). AKA: Sarah Baartman, the Hottentot Venus, and black women's identity. Women's Studies, 43(7), 946-959.

Henke, Winfried. (2007). Historical Overview of Paleoanthropological Research. In Winfried Henke \& Ian Tattersall (Eds.), Handbook of Paleoanthropology (pp. 1-56).

Hill, Kim R., Walker, Robert S., Božičević, Miran, Eder, James, Headland, Thomas, Hewlett, Barry, et al. (2011). Co-residence patterns in hunter-gatherer societies show unique human social structure. Science, 331(6022), 1286-1289.

Hodgson, Brian Houghton. (1848). Aborigines of Central India. Journal of the Asiatic Society of Bengal, $17,550-558$.

Hong, Lu, \& Page, Scott E. (2004). Groups of diverse problem solvers can outperform groups of highability problem solvers. Proceedings of the National Academy of Sciences, 101(46), 16385-16389.

Howell, F. Clark. (1957). The evolutionary significance of variation and varieties of "Neanderthal" man. The Quarterly Review of Biology, 32(4), 330-347.

Hrdlička, Aleš. (1904). Directions for Collecting Information and Specimens for Physical Anthropology (Vol. 39): US Government Printing Office.

Hrdlička, Aleš. (1921). The Peopling of Asia. Proceedings of the American Philosophical Society, 60(4), 535-545.

Hrdlička, Aleš. (1926). The Peopling of the Earth. Proceedings of the American Philosophical Society, 65(3), 150-156.

Hrdlička, Aleš. (1930). The Skeletal Remains of Early Man Smithsonian Institution Annual Report for 1928 (pp. 593-623). Washington, D.C.: Smithsonian Institution.

Hublin, Jean-Jacques, Ben-Ncer, Abdelouahed, Bailey, Shara E., Freidline, Sarah E., Neubauer, Simon, Skinner, Matthew M., et al. (2017). New fossils from Jebel Irhoud, Morocco and the pan-African origin of Homo sapiens. [Letter]. Nature, 546(7657), 289-292.

Huxley, Thomas Henry. (1863). On Some Fossil Remains of Man Evidence as to Man's Place in Nature. London and Edinburgh: Williams and Norgate.

Keith, Arthur. (1925). The Antiquity of Man. London: Williams and Norgate, Itd.

Keith, Arthur. (1929). The fossil man of Peking. The Lancet, 214(5535), 683-685. 
Kelly, Robert. (2013). Hunter Gatherers and Prehistory The Lifeways of Hunter-Gatherers: The Foraging Spectrum (pp. 269-300). New York: Cambridge University Press.

Kopytoff, Igor. (1987). The African Frontier: The Reproduction of Traditional African Societies: Indiana University Press.

Kuhlwilm, M., Gronau, I., Hubisz, M. J., de Filippo, C., Prado-Martinez, J., Kircher, M., et al. (2016). Ancient gene flow from early modern humans into Eastern Neanderthals. Nature, 530(7591), 429-433.

Kuljian, Christa. (2016). Darwin's Hunch : Science, Race and the Search for Human Origins. Auckland Park, South Africa: Jacana.

Langford, Ros F. 1983. "Our Heritage - Your Playground." Australian Archaeology (16):1-6.

Le Gros Clark, WE. (1947). The importance of the fossil Australopithecinae in the study of human evolution. Science Progress (1933-), 35(139), 377-395.

Leakey, Louis S. B. (1936). Stone Age Africa: An Outline of Prehistory in Africa: Oxford University Press, H. Milford.

MacCurdy, George Grant. (1922). The Skull from Broken Hill in Rhodesia. American Anthropologist, 24(1), 97-98.

Madley, Benjamin. 2005. "From Africa to Auschwitz: How German South West Africa Incubated Ideas and Methods Adopted and Developed by the Nazis in Eastern Europe." European History Quarterly 35 (3):429-464.

Marean, Curtis W. . (2014). The origins and significance of coastal resource use in Africa and Western Eurasia. Journal of Human Evolution, 77, 17-40.

Marean, Curtis W. . (2015a). The most invasive species of all. Scientific American, 313(2), 33-39.

Marean, Curtis W. . (2015b). Readers Respond to "How We Conquered the Planet", from https://www.scientificamerican.com/article/readers-respond-to-how-we-conquered-theplanet/

Marks, Jonathan. (2001). 'We're Going to Tell These People Who They Really Are': Science and Relatedness. Relative values: Reconfiguring kinship studies, 355-383.

Matthew, W. D. (1914). Climate and evolution. Annals of the New York Academy of Sciences, 24(1), 171318.

Mazrui, Ali Al'Amin. (2005). The re-invention of Africa: Edward Saïd, VY Mudimbe, and beyond. Research in African Literatures, 36(3), 68-82.

McNiven, Ian J, \& Russell, Lynette. (2008). Toward a Postcolonial Archaeology of Indigenous Australia. In R. Alexander Bentley, Herbert D.G. Maschner \& Christopher Chippindale (Eds.), Handbook of Archaeological Theories (pp. 423-443). Lanham: AltaMira Press.

Mivart, St George Jackson. (1873). Man and Apes; An Exposition of Structural Resemblances and Differences Bearing Upon Questions of Affinity and Origin. London: R. Hardwicke.

Morell, Virginia. (1995). Who owns the past? Science, 268(5216), 1424.

Movius, Hallam L., Jr. (1948). The Lower Palaeolithic cultures of Southern and Eastern Asia. Transactions of the American Philosophical Society, 38(4), 329-420.

Mudimbe, V. Y. (1994). The Idea of Africa. Bloomington, London: Indiana University Press; J. Currey.

Murray, Tim, \& Allen, Jim. (1995). The forced repatriation of cultural properties to Tasmania. Antiquity, 69(266), 871-874.

Osborn, Henry Fairfield. (1926). Why Central Asia? Natural History, 26, 263-269. 
Osborn, Henry Fairfield. (1927). Recent discoveries relating to the origin and antiquity of man. Science, 65(1690), 481-488.

Page, Scott E. (2007). The Difference: How the Power of Diversity Creates Better Groups, Firms, Schools, and Societies. Princeton: Princeton University Press.

Palladino, Paolo, \& Worboys, Michael. (1993). Science and imperialism. Isis, 84(1), 91-102.

Pels, Peter. (1998). From Texts to Bodies: Brian Houghton Hodgson and the Emergence of Ethnology in India. In Jan van Bremen \& Akitoshi Shimizu (Eds.), Anthropology and Colonialism in Asia and Oceania (pp. 65). London, New York: Routledge.

Pels, Peter. (1999). The rise and fall of the Indian aborigines. In Peter Pels \& Oscar Salemink (Eds.), Colonial Subjects: Essays on the Practical History of Anthropology (pp. 82-116). Ann Arbor: University of Michigan Press.

Pels, Peter. (2008). What has anthropology learned from the anthropology of colonialism? Social Anthropology, 16(3), 280-299.

Popkin, Richard H. 1974. "The Philosophical Bases of Modern Racism." In Philosophy and the Civilizing Arts: Essays Presented to Herbert W. Schneider on his 80th Birthday, edited by Craig Walton and John P. Antón.

Porr, Martin. 2014. "Essential questions: 'Modern humans' and the capacity for modernity." In Southern Asia, Australia and the Search for Human Origins, edited by Robin Dennell and Martin Porr, 257264. Cambridge: Cambridge University Press.

Porr, Martin, \& Matthews, Jacqueline M. (2017). Post-colonialism, human origins and the paradox of modernity. Antiquity, 91(358), 1058-1068.

Qiu, Jane. (2016). The forgotten continent. Nature, 535(7611), 218-220.

Reader, John. (1988). Missing Links: The Hunt for Earliest Man. London: Penguin Books.

Roque, Ricardo. (2011). Stories, skulls, and colonial collections. Configurations, 19(1), 1-23.

Saïd, Edward W. (1978). Orientalism. New York: Random House.

Scerri, Eleanor ML, Mark G Thomas, Andrea Manica, Philipp Gunz, Jay T Stock, Chris Stringer, Matt Grove, Huw S Groucutt, Axel Timmermann, and G Philip Rightmire. 2018. "Did our species evolve in subdivided populations across Africa, and why does it matter?" Trends in ecology \& evolution.

Schramm, Katharina. (2016). African Homecoming: Pan-African Ideology and Contested Heritage. London, New York: Routledge.

Schrire, Carmel. (1980). An inquiry into the evolutionary status and apparent identity of San huntergatherers. Human Ecology, 8(1), 9-32.

Schroeder, Lauren, \& Ackermann, Rebecca Rogers. (2017). Evolutionary processes shaping diversity across the Homo lineage. Journal of human evolution, 111, 1-17.

Scully, Pamela, \& Crais, Clifton. (2008). Race and erasure: Sara Baartman and Hendrik Cesars in Capetown and London. Journal of British Studies, 47(2), 301-323.

Shipman, Pat. (2001). The man who found the missing link : Eugène Dubois and his lifelong quest to prove Darwin right. New York: Simon \& Schuster.

Shipman, Pat, and Paul Storm. 2002. "Missing links: Eugène Dubois and the origins of paleoanthropology." Evolutionary Anthropology: Issues, News, and Reviews 11 (3):108-116.

Smith, Edwin W. (1935). Africa: What do we know of it? The Journal of the Royal Anthropological Institute of Great Britain and Ireland, 65, 1-81. 
Spencer, Frank, \& Smith, Fred H. (1981). The significance of Aleš Hrdlička on "the Neanderthal phase of man": A historical and current assessment. American Journal of Physical Anthropology, 56(4), 435-459.

Strkalj, G. (2000). Inventing races: Robert Broom's research on the Khoisan. Annals of the Transvaal Museum, 37, 113-124.

Sussman, Robert W. (2014). The Myth of Race: The Troubling Persistence of an Unscientific Idea. Cambridge, Massachusetts: Harvard University Press.

Sysling, Fenneke. (2015). 'Protecting the primitive natives': Indigenous people as endangered species in the early nature protection movement, 1900-1940. Environment and History, 21(3), 381-399.

TallBear, Kim. (2013). Native American DNA: Tribal Belonging and the False Promise of Genetic Science. Minneapolis: University of Minnesota Press.

Templeton, Alan R. (2002). Out of Africa again and again. Nature, 416, 45-51.

Terrell, John Edward. (2018, May 29, 2018). "Plug and Play" Genetics, Racial Migrations and Human History. https://blogs.scientificamerican.com/observations/plug-and-play-genetics-racialmigrations-and-human-history/.

Testart, Alain, Arcand, Bernard, Ingold, Tim, Legros, Dominique, Linkenbach, Antje, Morton, John, et al. (1988). Some major problems in the social anthropology of hunter-gatherers [and Comments and Reply]. Current Anthropology, 29(1), 1-31.

Thorne, Alan. (1981). The Centre and the Edge: The Significance of Australian Hominids to African Palaeoanthropology In R.E.F. Leakey \& B.A. Ogot (Eds.), Proceedings 8th Pan African Congress of Prehistory and Quaternary Studies (pp. 180-181). Nairobi: TILLMIAP.

Trinkaus, Erik. (2005). Early modern humans. Annual Review of Anthropology, 34, 207-230.

Trinkaus, Erik, and Pat Shipman. 1992. The Neandertals. New York: Vintage.

von Cramon-Taubadel, Noreen, \& Weaver, Timothy D. (2009). Insights from a quantitative genetic approach to human morphological evolution. Evolutionary Anthropology: Issues, News, and Reviews, 18(6), 237-240.

Wallace, Alfred Russel. (1889). Darwinism, An Exposition of the Theory of Natural Selection, With Some of its Applications. London: Macmillan and Company.

Washburn, Sherwood L. 1951. "Section of Anthropology: the "New Physical Anthropology"." Transactions of the New York Academy of Sciences 13 (7 Series II):298-304. doi: doi:10.1111/j.2164-0947.1951.tb01033.x.

Weaver, Timothy D., Roseman, Charles C., \& Stringer, Chris B. (2007). Were neandertal and modern human cranial differences produced by natural selection or genetic drift? Journal of Human Evolution, 53(2), 135-145.

White, Randall. (2006). The women of Brassempouy: A century of research and Interpretation. Journal of Archaeological Method and Theory, 13(4), 250-303.

Wolpoff, Milford, \& Caspari, Rachel. (1997). Race and Human Evolution. New York: Simon and Schuster.

Wolpoff, Milford, Wu, Xinzhi, \& Thorne, Alan. (1984). Modern Homo sapiens origins: A General Theory of Hominid Evolution Involving the Fossil Evidence from East Asia. In F.H. Smith \& F. Spencer (Eds.), The Origins of Modern Humans: A World Survey of the Fossil Evidence (pp. 411-483). New York: Alan R. Liss.

Woodward, Arthur Smith. (1922). The problem of the Rhodesian fossil man. Science Progress in the Twentieth Century (1919-1933), 16(64), 574-579. 
Wu, Xinzhi. (1988). Comparative study of early Homo sapiens from China and Europe. Acta Anthropologica Sinica, 7, 287-293.

Wu, Xinzhi. (2004). On the origin of modern humans in China. Quaternary International, 117(1), 131140.

Zambia, Government of the Republic of. (2016). Zambia's Quest for the Return of the Broken Hill Man Skull. Paper presented at the United Nations Educational, Scientific and Cultural Organisation (UNESCO) 20th Session of the Inter-Governmental Committee for Promoting the Return of Cultural Property to its Countries of Origin or its Restitution in Case of Illicit Appropriation 